\title{
Seed quality of rice cultivars stored in different environments ${ }^{1}$
}

\author{
Elizabeth Rosemeire Marques²*, Eduardo Fontes Araújo², Roberto Fontes Araújoº \\ Sebastião Martins Filho ${ }^{4}$, Plínio César Soares ${ }^{3}$
}

\begin{abstract}
The objective of this study was to evaluate dormancy and physiological quality of seeds of rice cultivars during storage in different environments. After harvesting, the seeds of three rice cultivars (Seleta, Curinga and Relâmpago) were dried in the sun, to reach moisture content at around $13 \%$. Then, they were packed in paper and stored in four environments: $5 \pm 2{ }^{\circ} \mathrm{C} / 70 \pm 5 \% \mathrm{RH}, 12 \pm 2{ }^{\circ} \mathrm{C} / 70 \pm 5 \% \mathrm{RH}, 18 \pm 2{ }^{\circ} \mathrm{C} / 65 \pm 5 \% \mathrm{RH}$ and in uncontrolled condition of temperature and relative humidity (natural). Physiological quality was evaluated at the beginning and at 3,6,9 and 12 months of storage by germination test, electrical conductivity, accelerated aging and sand emergence. The experiment was conducted in split plots in a completely randomized design with three replications. Environmental factor was applied in the plots, cultivars in the subplots and storage period in subplots. Cultivar Seleta showed higher dormancy, which was surpassed during storage regardless of environment conservation. In general, seeds stored in natural environment showed lower physiological quality. Only the seeds of cultivar Seleta, regardless of the environment, maintained germination above the minimum required for commercialization until six months of storage.
\end{abstract}

Index terms: Oryza sativa L., germination test, vigor test.

\section{Qualidade de sementes de cultivares de arroz armazenadas em diferentes ambientes}

\begin{abstract}
RESUMO - Objetivou-se avaliar a dormência e a qualidade fisiológica de sementes de cultivares de arroz durante o armazenamento em diferentes ambientes. Após a colheita, as sementes de três cultivares de arroz (Seleta, Curinga e Relâmpago) foram secas ao sol, até atingirem teor de água em torno de $13 \%$. Foram acondicionadas em embalagem de papel e armazenadas em quatro ambientes: $5 \pm 2{ }^{\circ} \mathrm{C} / 70 \pm 5 \% \mathrm{UR}, 12 \pm 2{ }^{\circ} \mathrm{C} / 70 \pm 5 \% \mathrm{UR}, 18 \pm 2{ }^{\circ} \mathrm{C} / 65 \pm 5 \% \mathrm{UR}$ e em condição não controlada de temperatura e umidade relativa (natural). A qualidade fisiológica foi avaliada no início e aos 3,6 , 9 e 12 meses de armazenamento pelos testes de germinação, condutividade elétrica, envelhecimento acelerado e emergência em areia. O experimento foi realizado no esquema de parcelas subsubdivididas no delineamento inteiramente casualizado com três repetições. O fator ambiente foi aplicado nas parcelas, cultivares nas subparcelas e tempo de armazenamento nas subsubparcelas. As sementes da cultivar Seleta apresentaram maior porcentagem de dormência, que foi superada durante o armazenamento independente do ambiente de conservação. Sementes armazenadas em ambiente natural apresentaram qualidade fisiológica inferior. Apenas as sementes da cultivar Seleta, independente do ambiente, mantiveram a germinação acima do mínimo exigido para comercialização até os seis meses de armazenamento.
\end{abstract}

Termos para indexação: Oryza sativa L., teste de germinação, teste de vigor.

\section{Introduction}

The seeds take to the agriculturist all the genetic potential of a cultivar with major characteristics. New improved cultivars become agricultural raw material whenever their high quality seeds are available to agriculturists and are sowed by them (Peske

\footnotetext{
${ }^{1}$ Submitted on 06/28/2013. Accepted for publication on 11/23/2013.

${ }^{2}$ Departamento de Fitotecnia, Universidade Federal de Viçosa, 36570-000 -

Viçosa, MG, Brasil.

${ }^{3}$ Empresa de Pesquisa Agropecuária de Minas Gerais, Caixa Postal 216, 36571-000 - Viçosa, MG, Brasil.
}

et al., 2006). Maintaining the seed quality during the storage period is a factor that must be considered in the production process of any crop, for the farming success depends, mainly, on the use of high quality seeds (Freitas et al., 2004). For rice seeds in Brazil, the minimum required for production and commercialization is $80 \%$, regardless of the category (Brasil, 2005).

\footnotetext{
${ }^{4}$ Departamento de Estatística, Universidade Federal de Viçosa, 36570-000 Viçosa, MG, Brasil.

*Corresponding author < bethagro@yahoo.com.br>
} 
In most crops that are spread by seeds, the harvesting season does not overlap the sowing season and, for this reason, the seeds are stored in order to maintain their productive potential (Souza et al., 2007). During the storage, several aspects have a direct effect on the seeds feasibility, such as: water content in the storage, conservation packages, temperature and relative humidity of the air and the storage environment, gas exchange and characteristics of the seed skin (Caldwell et al., 2005; Toledo et al., 2009).

For the internal quality control program of seed production companies, monitoring the physiological potential of dormant rice seeds is extremely important, mainly when the aim is to define the speed of inactivity surpassing (Vieira et al., 2000). The behavior differs in accordance with the cultivar and the cultivation system; the dormancy is more intense in lowland.

Evaluating the physiological potential of seeds is also very important for the internal quality control program of seed production companies to characterize the seeds that are ready to be commercialized (Ávila et al, 2006). Among the tests used for this evaluation, the accelerated aging test is indicated to define the seeds' vigor (Marcos- Filho, 2005) and, as a consequence, their storage potential, because it delays the germination process and the embryo's growth (Maia et al., 2007). This test is used in order to evaluate the physiological potential of seeds after certain storage period (Panobianco et al., 2007).

The electrical conductivity test has been used to evaluate the seeds' vigor in several species for being simple to execute, of low cost, fast, replicable and with easy interpreting results (Vieira and Krzyzanowski, 1999). It is indicated to detect the seeds deterioration rate during the storage period (Abreu et al., 2011; Panobianco et al., 2007).

Therefore, this paper aims at evaluating the dormancy and the behavior of the seeds physiological quality in rice cultivars of lowlands and highlands during the storage under different environmental conditions.

\section{Material and Methods}

This research was conducted in the Phytotechny Department of Universidade Federal de Viçosa, Viçosa-MG, with seeds from three rice cultivars: the lowland cultivar BRSMG Seleta and the highland cultivars BRSMG Curinga and BRSMG Relâmpago, which present great genetic potential characteristics for the production of grains, premature to median cycle, good culinary and industrial quality of grains. These cultivars were produced by Empresa de Pesquisa Agropecuária de Minas Gerais (EPAMIG), in Lambari-MG, in the harvest of 2009/2010.

After the harvest, the seeds were dried in the sun until they reached a water content of $13 \%$.

The seeds were placed in paper bags and stored in four environments: cold chamber $1\left(5 \pm 2{ }^{\circ} \mathrm{C}, 70 \pm 5 \%\right.$ relative humidity), cold chamber $2\left(12 \pm 2{ }^{\circ} \mathrm{C}, 70 \pm 5 \%\right.$ relative humidity), air conditioned room $\left(18 \pm 2{ }^{\circ} \mathrm{C}, 65 \pm 5 \%\right.$ relative humidity) and natural environment (without neither temperature nor relative humidity control). During the storage, the temperature and relative humidity of the environments were monitored (Figure 1).

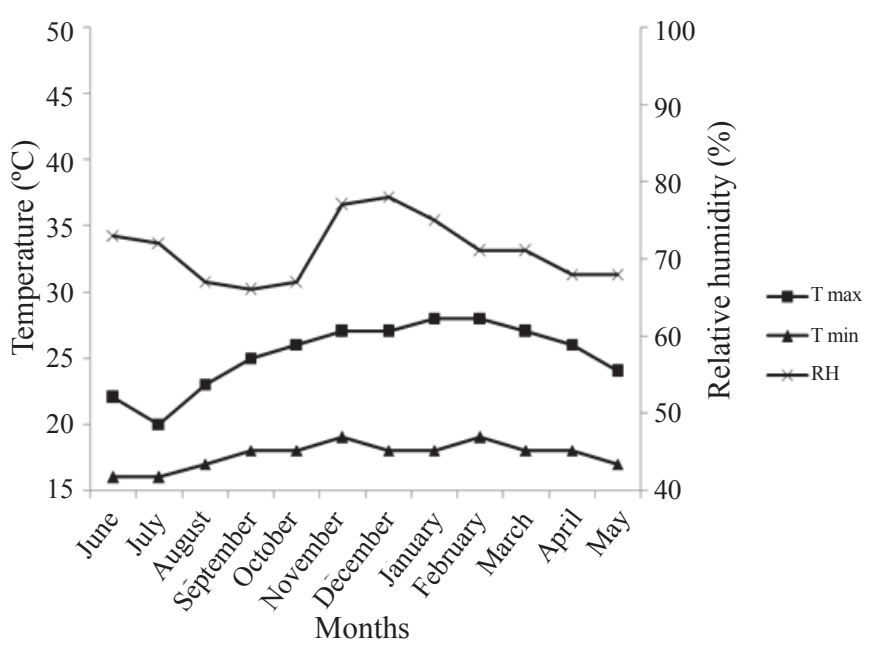

Figure 1. Monthly averages of maximum (Tmax) and minimum (Tmin) temperatures and relative air humidity in natural environment, from June 2010 (beginning of experiment) to May 2011 (end of experiment).

The seeds were evaluated before the storage and 3, 6, 9 and 12 months after it, in accordance with the following methodologies:

Water content - defined by the oven method at $105^{\circ} \mathrm{C}$, for 24 hours, using two samples of each replication, in accordance with the Rules for Seed Testing (Brasil, 2009). The results were expressed in percentage of water content.

Germination - four samples with 50 seeds for each replication were used; they were treated with $2,4 \mathrm{~g}$ of fungicide Captan for each kilogram of seeds. Then, they were sowed in towel paper ( 3 sheets) moistened with distilled water in a ratio of 2.5 times its dry weight. The paper rolls were kept in a germinator at $25^{\circ} \mathrm{C}$. The evaluations were made 5 and 14 days after the sowing. The results were expressed in percentage of normal seedlings (Brasil, 2009).

Accelerated aging - plastic boxes with lid (gerbox) with $40 \mathrm{~mL}$ of distilled water were used. Above the water, a screen with seeds in one layer was placed; for each replication, four samples with 50 seeds were used. After that, the boxes were kept in B.O.D. at $42{ }^{\circ} \mathrm{C}$ for 120 hours. After this aging period, the seeds were removed from the chambers in order 
to conduct the germination tests, as described above, and the normal seedlings were calculated five days after the sowing (Brasil, 2009). The results were expressed in percentage.

Electrical conductivity - it was conducted with four samples of 50 seeds for each replication. The samples were previously weighted in a precision scale and put in a cup with $75 \mathrm{~mL}$ of deionized water. The cups, containing water and seeds, were placed in a germination chamber (BOD type) and kept under constant temperature of $25^{\circ} \mathrm{C}$. After 24 hours of soaking, the electrical conductivity was determined with a Digimed CD-21 conductivity meter, in accordance with the methodology described by Vieira and Krzyzanowski (1999). The results were expresses in $\mu \mathrm{S} . \mathrm{cm}^{-1} \cdot \mathrm{g}^{-1}$ of seeds.

Emergence in greenhouse - the seeds were sowed on plastic trays, using sand as substratum. The sowing was made in rows $10 \mathrm{~cm}$ apart and $3 \mathrm{~cm}$ deep, with 4 samples of 50 seeds for each replication. The substratum moisture was maintained with daily irrigation. The number of emerged seedlings was calculated after 21 days. The results were expressed in percentage.

Statistical design - the experiment was conducted in split plots in a completely randomized design with three replications. Environmental factor was applied in the plots, cultivars in the subplots and storage period in subplots. For the variance analysis, regardless of the relevance, the option was to expand environment $\mathrm{x}$ cultivar $\mathrm{x}$ storage interaction. The regression analysis was made for the storage period. The data were analyzed by the Statistical and Genetic Analysis System - SAEG (SAEG, 2007).

\section{Results and Discussion}

When characterizing the germination and dormancy in seeds of recently harvested rice cultivars (Table 1), it was possible to note low percentage of dormancy among the cultivars. The highest percentage was found for cultivar Seleta (13\%), which is a lowland cultivar. The other seeds of highland cultivars virtually did not present dormancy $(6 \%$ for Curinga and 2\% for Relâmpago). Vieira et al. (2002) also observed that the dormancy is more intense right after the harvest in lowland cultivars when compared with the highland ones.

Table 2 shows the results of the seeds' water content from three rice cultivars, during the storage in different environments. The initial water content ranged from 13,0\% to $13,7 \%$. During the storage, the water content variation was less than $1 \%$, which means that, in these storage conditions, the water content of the cultivar seeds was close to hygroscopic equilibrium due to the storage.
Table 1. Results for germination and dormancy of seeds of rice cultivars before storage.

\begin{tabular}{ccc}
\hline Cultivars & Germination (\%) & Dormancy (\%) \\
\hline Seleta & $66 \mathrm{C}$ & $13 \mathrm{~A}$ \\
Curinga & $77 \mathrm{~B}$ & $6 \mathrm{~B}$ \\
Relâmpago & $82 \mathrm{~A}$ & $2 \mathrm{C}$ \\
\hline
\end{tabular}

Averages followed by the same letter do not present relevant difference at $5 \%$ of probability level by Tukey's test.

For cultivar Seleta, it was possible to note the maximum germination (Figure 2), corresponding to the overcome dormancy period, occurred after 6,$8 ; 6,2 ; 7,0$ and 6,6 months of storage, in $5{ }^{\circ} \mathrm{C}, 12{ }^{\circ} \mathrm{C}, 18{ }^{\circ} \mathrm{C}$ and natural environments, respectively. The maximum seedling emergence (Table 3 ) occurred after 5,6; 5,3 and 5,7 months, in $5{ }^{\circ} \mathrm{C}, 12^{\circ} \mathrm{C}$ and natural environments; there was no effect of the storage period at $18^{\circ} \mathrm{C}$.

For cultivar Curinga, the seed germination (Figure 2) was not affected by the storage period at $5{ }^{\circ} \mathrm{C}, 12{ }^{\circ} \mathrm{C}$ and natural environment; at $18{ }^{\circ} \mathrm{C}$, there was a slight increase in germination until 5,8 months. The seedlings emergence (Figure 3) was not affected during the seeds storage at $5{ }^{\circ} \mathrm{C}$, $18^{\circ} \mathrm{C}$ and natural environment; the conservation of seeds at $12^{\circ} \mathrm{C}$ caused a slight increase in germination until 5,6 months.

For cultivar Relâmpago, the seed germination (Figure 2) remained constant during the storage at $5{ }^{\circ} \mathrm{C}, 12^{\circ} \mathrm{C}$ and $18{ }^{\circ} \mathrm{C}$; in natural environment, there was a slight increase until 3,1 months. Figure 3 shows that there was no change in the seedling emergence during the seeds storage at $12^{\circ} \mathrm{C}$; there was increase in emergence until 3,0; 5,6 and 2,2 months of storage at $5{ }^{\circ} \mathrm{C}, 18{ }^{\circ} \mathrm{C}$ and natural environments, respectively.

The increase on germination and emergence of seedlings from cultivar Seleta may be explained by the dormancy overcome, which was $13 \%$ at the beginning of the storage period (Table 1). For cultivars Curinga and Relâmpago, the percentage of dormant seeds was very low, $6 \%$ and $2 \%$ respectively, and this fact does not explain the germination and emergence increases occurred during the storage (Figures 2 and 3 ).

By analyzing, altogether, the initial germination and dormancy results (Table 1) and the germination and emergence during storage (Figures 2 and 3), it is possible to note that cultivars Curinga and Relâmpago did not present dormant seeds. For cultivar Seleta, in general, the seed dormancy was broken after 5 to 7 months of storage, regardless of the conservation environment, showing that there was no effect of the environment temperature on the time period needed for this cultivar to break the dormancy. Different from the present study, Vieira et al. (2008) verified that seeds stored in conventional environments break the dormancy faster than seeds stored in cold and dry chambers. 
Table 2. Water content (\%) of seeds of rice cultivars, during the storage in different environment conditions.

\begin{tabular}{|c|c|c|c|c|}
\hline \multirow{2}{*}{$\begin{array}{l}\text { Storage period } \\
\text { (months) }\end{array}$} & \multirow{2}{*}{ Environments } & \multicolumn{3}{|c|}{ Cultivars } \\
\hline & & Seleta & Curinga & Relâmpago \\
\hline \multirow{4}{*}{0} & $5{ }^{\circ} \mathrm{C} / 70 \% \mathrm{RH}$ & $13.6 \mathrm{aA}^{1 /}$ & $13.7 \mathrm{aA}$ & $13.0 \mathrm{aB}$ \\
\hline & $12{ }^{\circ} \mathrm{C} / 70 \% \mathrm{RH}$ & $13.6 \mathrm{aA}$ & $13.7 \mathrm{aA}$ & $13.0 \mathrm{aB}$ \\
\hline & $18^{\circ} \mathrm{C} / 65 \% \mathrm{RH}$ & $13.6 \mathrm{aA}$ & $13.7 \mathrm{aA}$ & $13.0 \mathrm{aB}$ \\
\hline & Natural & $13.6 \mathrm{aA}$ & $13.7 \mathrm{aA}$ & $13.0 \mathrm{aB}$ \\
\hline \multirow{4}{*}{3} & $5{ }^{\circ} \mathrm{C} / 70 \% \mathrm{RH}$ & $12.8 \mathrm{bB}$ & $13.1 \mathrm{abA}$ & $12.8 \mathrm{cB}$ \\
\hline & $12{ }^{\circ} \mathrm{C} / 70 \% \mathrm{RH}$ & $12.8 \mathrm{bB}$ & $12.8 \mathrm{cB}$ & $13.3 \mathrm{abA}$ \\
\hline & $18^{\circ} \mathrm{C} / 65 \% \mathrm{RH}$ & $13.0 \mathrm{abA}$ & $12.9 \mathrm{bcA}$ & $13.0 \mathrm{bA}$ \\
\hline & Natural & $13.2 \mathrm{aA}$ & $13.3 \mathrm{aA}$ & $13.4 \mathrm{aA}$ \\
\hline \multirow{4}{*}{6} & $5{ }^{\circ} \mathrm{C} / 70 \% \mathrm{RH}$ & $13.5 \mathrm{aA}$ & $13.5 \mathrm{aA}$ & $13.1 \mathrm{bB}$ \\
\hline & $12{ }^{\circ} \mathrm{C} / 70 \% \mathrm{RH}$ & $13.7 \mathrm{aA}$ & $13.5 \mathrm{aA}$ & $13.6 \mathrm{aA}$ \\
\hline & $18^{\circ} \mathrm{C} / 65 \% \mathrm{RH}$ & $13.1 \mathrm{bB}$ & $13.3 \mathrm{bB}$ & $13.7 \mathrm{aA}$ \\
\hline & Natural & $13.5 \mathrm{aA}$ & $13.5 \mathrm{aA}$ & $13.6 \mathrm{aA}$ \\
\hline \multirow{4}{*}{9} & $5{ }^{\circ} \mathrm{C} / 70 \% \mathrm{RH}$ & $14.0 \mathrm{bA}$ & $14.0 \mathrm{bA}$ & $14.2 \mathrm{aA}$ \\
\hline & $12{ }^{\circ} \mathrm{C} / 70 \% \mathrm{RH}$ & $14.0 \mathrm{bA}$ & $14.0 \mathrm{bA}$ & $14.0 \mathrm{aA}$ \\
\hline & $18^{\circ} \mathrm{C} / 65 \% \mathrm{RH}$ & $13.8 \mathrm{cA}$ & $13.8 \mathrm{cA}$ & $13.8 \mathrm{bA}$ \\
\hline & Natural & $14.5 \mathrm{aA}$ & $14.6 \mathrm{aA}$ & $14.2 \mathrm{aB}$ \\
\hline \multirow{4}{*}{12} & $5{ }^{\circ} \mathrm{C} / 70 \% \mathrm{RH}$ & $13.8 \mathrm{aB}$ & $13.7 \mathrm{bB}$ & $14.0 \mathrm{aA}$ \\
\hline & $12{ }^{\circ} \mathrm{C} / 70 \% \mathrm{RH}$ & $13.8 \mathrm{aA}$ & $13.8 \mathrm{abA}$ & $13.6 \mathrm{bcB}$ \\
\hline & $18^{\circ} \mathrm{C} / 65 \% \mathrm{RH}$ & $13.4 \mathrm{bA}$ & $13.3 \mathrm{cA}$ & $13.4 \mathrm{cA}$ \\
\hline & Natural & $14.0 \mathrm{aA}$ & $14.1 \mathrm{aA}$ & $13.8 \mathrm{bB}$ \\
\hline
\end{tabular}

${ }^{1 /}$ Averages followed by the same lowercase letter in the column and same capital letter in the line do not present relevant difference at $5 \%$ of probability level by Tukey's test.
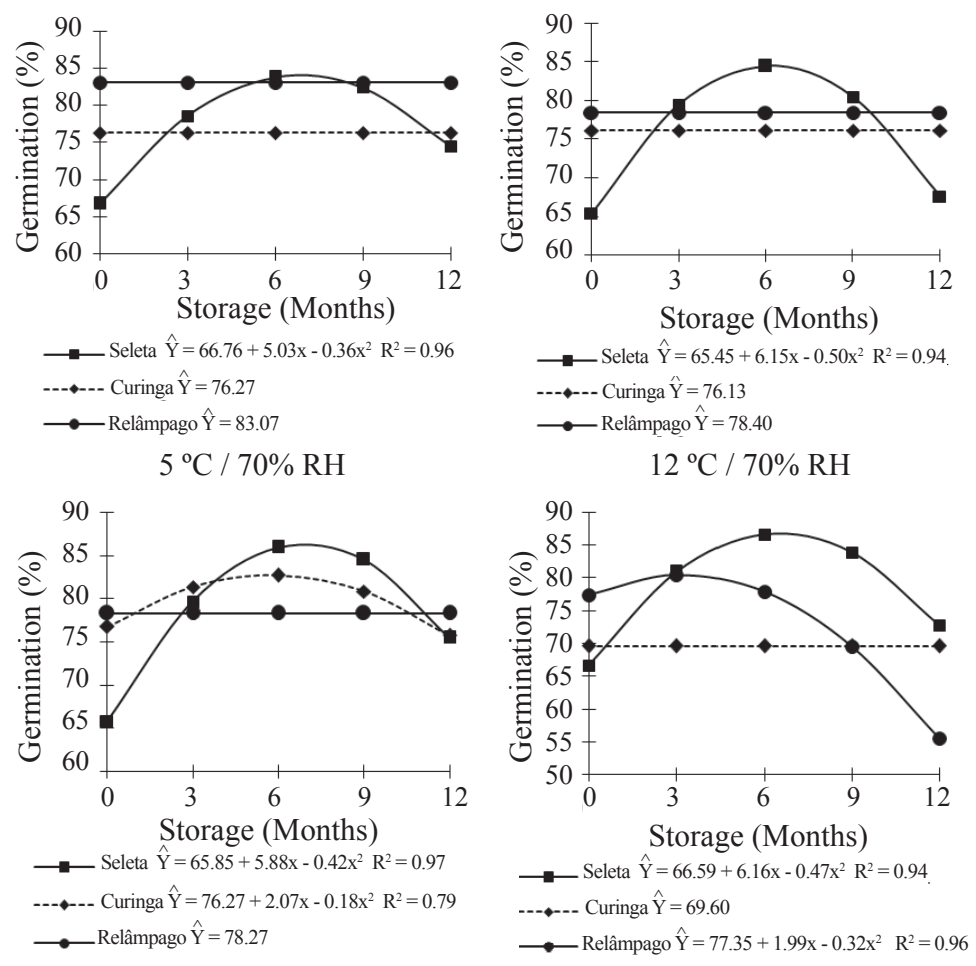

$18{ }^{\circ} \mathrm{C} / 65 \% \mathrm{RH} \quad$ Natural environment

Figure 2. Germination (\%) of seeds of rice cultivars during the storage in different environments. 

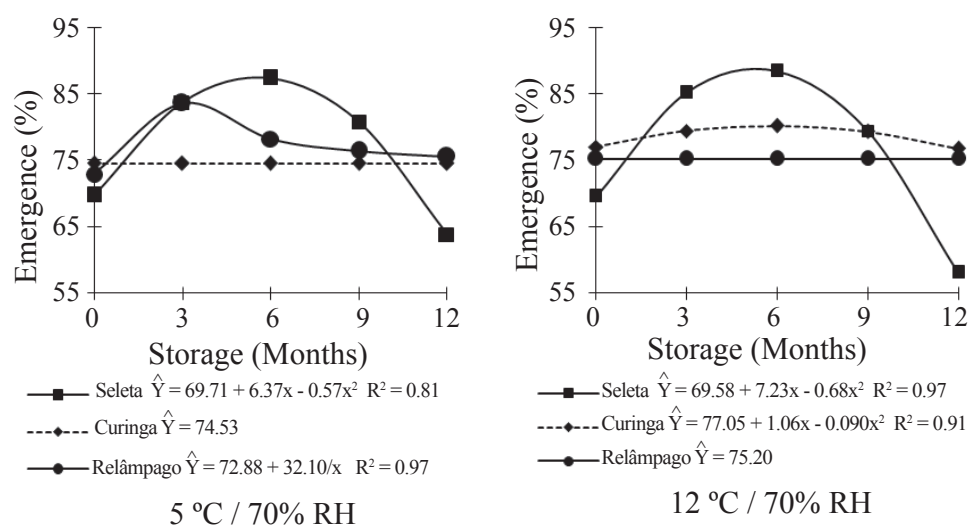

$12{ }^{\circ} \mathrm{C} / 70 \% \mathrm{RH}$

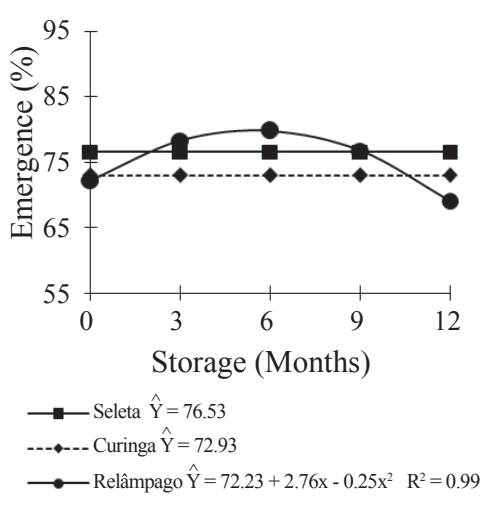

$18{ }^{\circ} \mathrm{C} / 65 \% \mathrm{RH}$

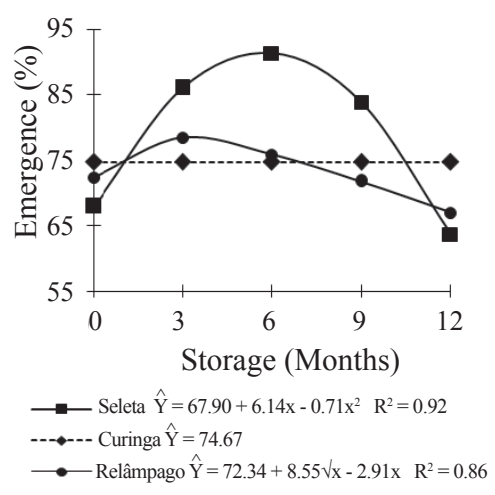

Natural environment

Figure 3. Emergence of seedlings from seeds of rice cultivars during the storage in different environments.

In cases where there was break dormancy, regardless of the cultivar and storage environment, after the maximum germination was reached, a process of natural deterioration of seeds initiated, resulting in a reduction of the germination. In general, the deterioration behavior was the same in all four storage environments, except for the cultivar Seleta seeds that were stored at $12{ }^{\circ} \mathrm{C}$ and cultivar Relâmpago seeds in natural environment. In these conditions, after 12 months of storage, the seeds from cultivars Seleta and Relâmpago presented less than $70 \%$ of germination. For the remaining treatments (cultivar and environment), after 12 months, the germination was higher than $70 \%$.

Macedo et al. (1999) evaluated rice seeds stored for 12 months in the city of Campinas - SP, Brazil, with average relative humidity of $72 \%$ and average temperature of $21{ }^{\circ} \mathrm{C}$, and observed a gradual reduction in germination starting on the eighth month.

The seed vigor, given by the accelerated aging test (Figure 4), did not change during the storage at $5{ }^{\circ} \mathrm{C}$ for cultivars Seleta and Curinga; at $12{ }^{\circ} \mathrm{C}$ for cultivar Relâmpago; at $18{ }^{\circ} \mathrm{C}$ for cultivars Seleta and Relâmpago and in natural environment for cultivars Curinga and Relâmpago. When there was decrease after reaching the maximum vigor, only cultivar Seleta at $12{ }^{\circ} \mathrm{C}$ and in natural environment presented less vigor than the initial after 12 months of storage.

Silva et al. (2010), when studying rice, corn and beans seeds stored under natural conditions in the state of Mato Grosso, which usually presents average annual temperature of $26^{\circ} \mathrm{C}$ and average relative humidity of $75 \%$, observed a reduction of vigor, by the accelerated aging test, after the second month of storage, regardless of the package used. However, Macedo et al. (1999), evaluating the rice seeds stored for 12 months, in Campinas - SP, Brazil, with average relative humidity of $72 \%$ and average temperature of $21{ }^{\circ} \mathrm{C}$, observed a reduction of vigor after the sixth month of storage.

The seedlings emergence percentage was not affected during the storage of seeds from cultivar Curinga in all four environments. Cultivar Seleta, with 12 months of storage, presented a lower emergence percentage in relation with the initial storage period, except for the $18{ }^{\circ} \mathrm{C}$ environment. The same happened with cultivar Relâmpago, when the seeds were stored at $18^{\circ} \mathrm{C}$ and in a natural environment. In general, it was possible to note that the behavior of the emergence percentage (Figure 3) was similar to the germination behavior (Figure 2).

The seed vigor, obtained by the electrical conductivity test (Figure 5), was affected during the storage only for cultivar Seleta in $5{ }^{\circ} \mathrm{C}, 12{ }^{\circ} \mathrm{C}$ and natural environments, and for cultivar 
Curinga at $5{ }^{\circ} \mathrm{C}$; after six months of storage the conductivity increase and, consequently, reduction of vigor was already detected. These results indicate that the storage period increase

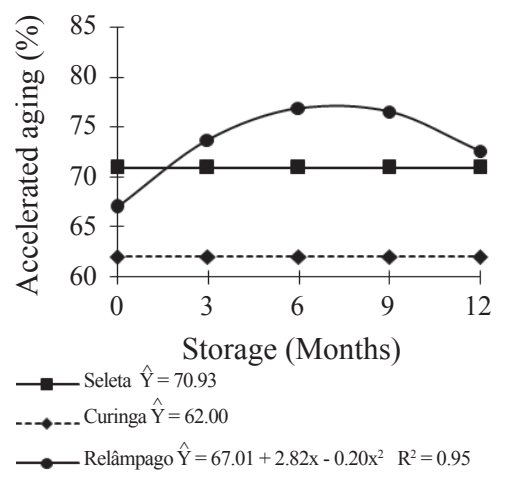

$5{ }^{\circ} \mathrm{C} / 70 \% \mathrm{RH}$

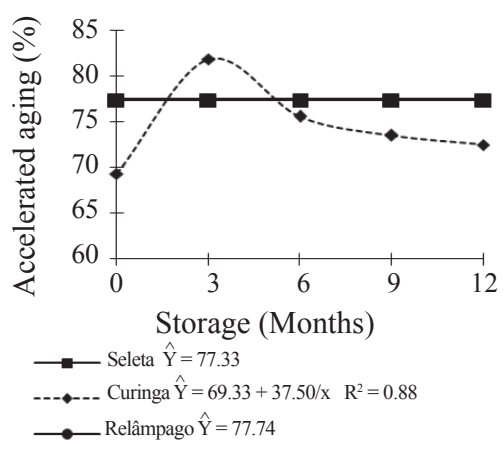

$18^{\circ} \mathrm{C} / 65 \% \mathrm{RH}$ causes the molecules activation energy to be intensified, altering the water viscosity and, consequently, increasing the electrical conductivity values (Alves and Sá, 2009).

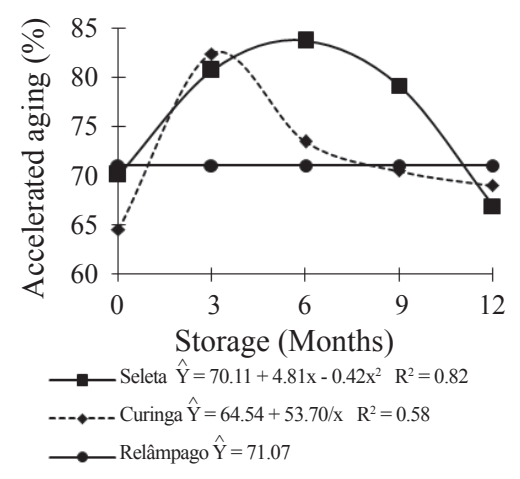

$12{ }^{\circ} \mathrm{C} / 70 \% \mathrm{RH}$

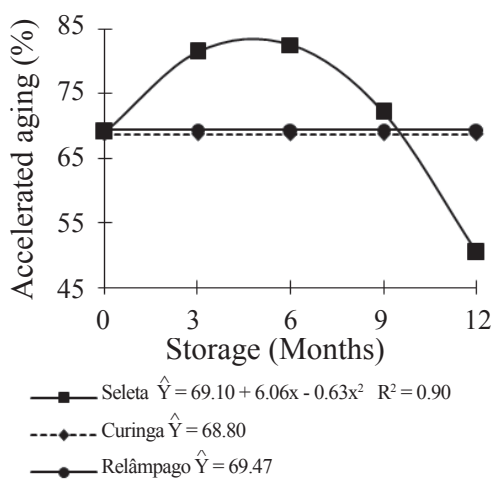

Natural environment

Figure 4. Vigor (\%), by the accelerated aging test of seeds of rice cultivars during the storage in different environments.

In general, the high vigor of the seed lots after six months of storage corresponds with the break dormancy of these cultivars, and also in this period, it was possible to not the maximum germination.

By the vigor tests used in this study, it was possible to verify that, as the storage period increased, there was a more significant deterioration of the seeds. The deterioration, in theory, begins with the physiological maturation; however, it is more frequently detected during the storage. The physiological potential decrease along the time period is not restricted to the germination capacity reduction, but it gets slower, and the sensitivity to environmental adversities is emphasized, characterizing the vigor decrease (Marcos-Filho, 2005).

Once the seed reaches the maximum physiological quality, that means, the maximum level of germination and vigor, a continuous and irreversible process of deterioration begins. The deterioration process in seeds involves a sequence of biochemical and physiological alterations that occur right after the physiological maturity, and which cause a reduction of vigor, resulting in loss of the germination capacity. It is not possible to avoid this process; however, it may be delayed when the storage is made under favorable conditions, mainly regarding the temperature and relative humidity.

In this study, as the relative humidity was similar in all the storage environments, resulting in seeds with very low water content variation during the storage period (Table 2), the difference in the seed vigor was caused by the temperature differences. In general, seeds stored in environments with 5,12 and $18{ }^{\circ} \mathrm{C}$ of temperature presented, in the end of the storage, higher germination and vigor when compared with seeds stored in natural environment. In this environment, the temperature was above $25^{\circ} \mathrm{C}$ during 8 months, contributing for the deterioration of the seeds. The temperature is an important factor for the seeds conservation, directly affecting the speed of biochemical processes, and indirectly interfering with the water content, resulting in other processes, such as the increase of enzymes activities (hydrolytic enzymes) and free fat acids. Also, the temperature increases the enzymatic and metabolic 
reactions rate, causing acceleration of the seeds deterioration speed. This important relation may evidence the initial process of the seeds deterioration sequence and, the physiological alterations

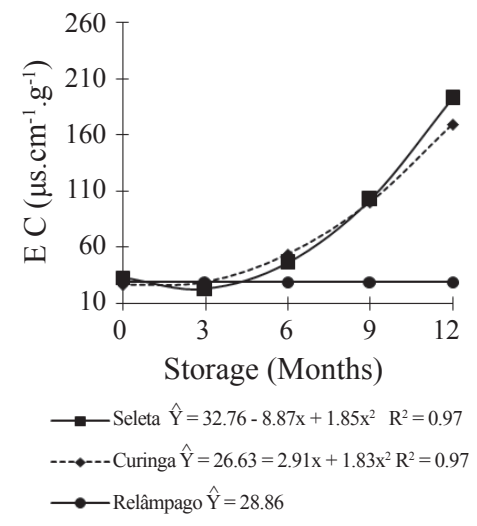

$5{ }^{\circ} \mathrm{C} / 70 \% \mathrm{RH}$

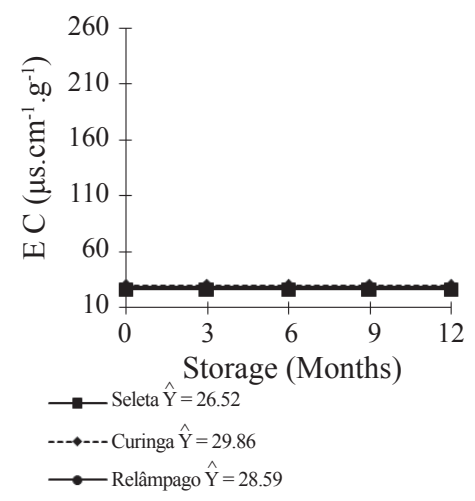

$18^{\circ} \mathrm{C} / 65 \% \mathrm{RH}$ of the seeds are directly related with the integrity of their cell membranes (Carvalho et al., 2009) which depends on the nature of the structural enzymes and protein of each species.

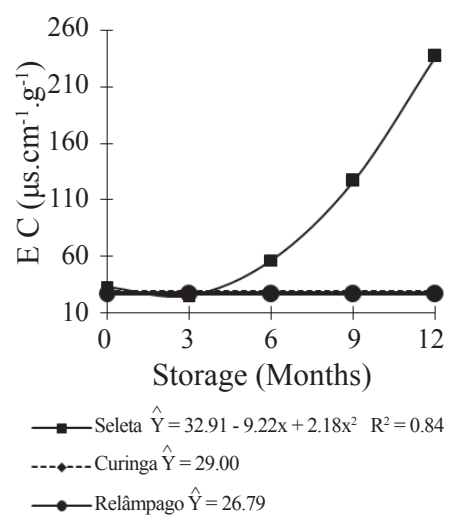

$12{ }^{\circ} \mathrm{C} / 70 \% \mathrm{RH}$

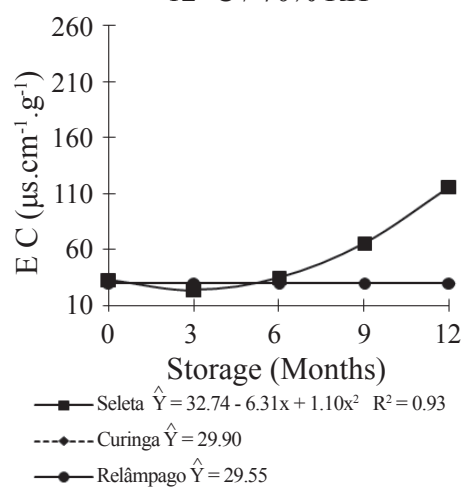

Natural environment

Figure 5. Vigor, by the electrical conductivity (EC) test of seeds of rice cultivars during the storage in different environments.

\section{Conclusions}

Cultivar Seleta presented higher dormancy percentage, which was surpasses during the storage period regardless the conservation environment.

In general, the seeds that were stored in natural environment presented lower physiological quality.

Only the seeds from cultivar Seleta, regardless of the environment, maintained the germination above the requirement for commercialization until six months of storage.

\section{Acknowledgment}

To CNPq (National Council for Scientific and Technological Development) for granting the scholarship and to FAPEMIG (Research Support Foundation of the State of Minas Gerais) for providing funds for this study.

\section{References}

ABREU, L.A.S.; CARVALHO, M.L.M.; PINTO, C.A.G.; KATAOKA, V.Y. Teste de condutividade elétrica na avaliação de sementes de girassol armazenadas sob diferentes temperaturas. Revista Brasileira de Sementes, vol. $33, n^{\circ} 4$, p. 635 - 642, 2011. www.scielo.br/pdf/rbs/v33n4/05.pdf

ALVES, C.Z.; SÁ, M.E. Teste de condutividade elétrica na avaliação do vigor de sementes de rúcula. Revista Brasileira de Sementes, v. 31, n. 01, p. $203-$ 215, 2009. http://dx.doi.org/10.1590/S0101-31222009000100023

ÁVILA, P.V.; VILLELA, F.A.; ÁVILA, M.S.V. Teste de envelhecimento acelerado para avaliação do potencial fisiológico de sementes de rabanete. Revista Brasileira de Sementes, v. 28, n. 3, p. 52-58, 2006. www.scielo.br/pdf/rbs/v28n3/08.pdf

BRASIL. Ministério da Agricultura, Pecuária e Abastecimento. Regras para Análise de Sementes. Ministério da Agricultura, Pecuária e Abastecimento. Secretaria de Defesa Agropecuária. - Brasília: Mapa/ACS, 2009. 395p. www.bs.cca.ufsc.br/publicacoes/regras analise sementes.pdf

BRASIL. Ministério de Agricultura, Pecuária e Abastecimento. Instrução normativa $\mathrm{n}^{\circ} 25$, de 16 de dezembro de 2005 . Padrões para produção e comercialização de sementes de arroz. Anexo II. Diário Oficial da República Federativa do Brasil, Poder Executivo, Brasília, DF, 20 dez. 2005. Seção 1, p.243. www.agricultura.pr.gov.br/arquivos/File/PDF/padroes_arroz.pd 
CALDWELL, C.R.; BRITZ, S.J.; MIRECKI, R.M. Effect of temperature, elevated carbon dioxide, and drought during seed development on the isoflavone content of dwarf soybean [ Glycine max (L.) Merrill] grown in controlled environments. Journal of Agricultural and Food Chemistry, Washington, v. 53, n. 4, p. 1125-1129, 2005. www.ncbi.nlm.nih.gov/pubmed/15713029

CARVALHO, L. F.; SEDIYAMA, C.S.; REIS, M.S.; DIAS, D.C.F.S.; MOREIRA, M.A. Influência da temperatura de embebição da semente de soja no teste de condutividade elétrica para avaliação da qualidade fisiológica. Revista Brasileira de Sementes, v. 41, n. 01, p. 9-17, 2009. www.scielo.br/ $\mathrm{pdf} / \mathrm{rbs} / \mathrm{v} 31 \mathrm{n} 1 / \mathrm{a} 01 \mathrm{v} 31 \mathrm{n} 1 . \mathrm{pdf}$

FREITAS, R.A.; DIAS, D.C.F.S.; DIAS, L.A.S.; OLIVEIRA, M.G.A. Testes fisiológicos e bioquímicos na estimativa do potencial de armazenamento de sementes de algodão. Revista Brasileira de Sementes, v. 26, n1, p.84-91, 2004. www.scielo.br/pdf/rbs/v26n1/a13v26n1.pdf

MACEDO, E.C.; GROTH, D.; SOAVE, J. Influência da embalagem e do armazenamento na qualidade fisiológica de sementes de arroz. Revista Brasileira de Sementes, v.21, n.1, p.67-75, 1999. www.abrates.org.br/revista/ artigos/1999/v21n1/artigo10.pdf

MAIA, A.R.; LOPES, J. C.; TEIXEIRA, C.O. Efeito do envelhecimento acelerado na avaliação da qualidade fisiológica de sementes de trigo. Ciência e Agrotecnologia, v. 31, n. 3, p. 678-684, 2007. www.editora.ufla.br/revista/ numero/idn/15/idv/31/idr/1

MARCOS- FILHO, J. Fisiologia de sementes de plantas cultivadas. Piracicaba: FEALQ, 2005. 495p.

PANOBIANCO, M.; VIEIRA, R. D.; PERECIN, D. Electrical conductivity as an indication of pea seed aging of stored at different temperatures. Scientia Agricola, v. 64, n. 2, p. 119-124 2007. www.scielo.br/pdf/sa/v64n2/a03v64n2.pd

PESKE, S.T.; LUCCAFILHO, O.A.; BARROS,A.C.S.A. Sementes: fundamentos científicos e tecnológicos. 2.ed., Pelotas: Universitária/UFPel, 2006, 470p.

SAEG - Sistema para Análises Estatísticas, Versão 9.1: Fundação Arthur Bernardes - UFV - Viçosa, 2007.
SILVA, F.S.; PORTO, A.G.; PASCUALI, L.C.; SILVA, F.T.C. Viabilidade do armazenamento de sementes em diferentes embalagens para pequenas propriedades rurais. Revista de Ciências Agro-Ambientais, v.8, n.1, p. 45-56, 2010. www.unemat.br/revistas/rcaa/docs/vol8/5_artigo_v8.pdf

SOUZA, J. R. P.; TAKAHASHI, L. S. A.; YOSHIDA, A. E.; GUIRAUD, M. C.; ROCHA, J N. Tempo de armazenamento e temperatura na porcentagem e velocidade de germinação das sementes de camomila. Ciência Rural, v. 37, n. 4, p. 982-986, 2007. www.scielo.br/pdf/cr/v37n4/a10v37n4.pdf

TOLEDO, M.Z.; FONSECA, N.R.; CESAR, M.L.; SORATTO, R.P.; CAVARIANI, C.; CRUSCIOL, C.A.C. Qualidade fisiológica e armazenamento de sementes de feijão em função da aplicação tardia de nitrogênio em cobertura. Pesquisa Agropecuária Tropical, v.39, n.2, p.124133, 2009. http://www.revistas.ufg.br/index.php/pat/issue/view/664

VIEIRA, A. R.; OLIVEIRA, J. A.; GUIMARÃES, R. M.; VON PINHO, E. V. R.; PEREIRA, C. E.; CLEMENTE, A. C. S. Marcador isoenzimático de dormência em sementes de arroz. Revista Brasileira de Sementes, v. 30, n. 1, p. 81-89, 2008. www.scielo.br/pdf/rbs/v30n1/a11v30n1.pdf

VIEIRA, A. R.; VIEIRA, M. G. G. C.; OLIVEIRA, J. A.; SANTOS, C. D. Alterações fisiológicas e enzimáticas em sementes dormentes de arroz armazenadas em diferentes ambientes. Revista Brasileira de Sementes, v. 22, n.2, p. $53-61,2000$. www.abrates.org.br/revista/artigospublicados/indice.php? $\mathrm{v}=22$

VIEIRA, A.R.; OLIVEIRA, J.A.; VIEIRA, M.G.G.C.; FRAGA, A.C.; SANTOS, C.D. Action of gibberellic acid $\left(\mathrm{GA}_{3}\right)$ on dormancy and activity of alfa-amylase in rice seeds. Revista Brasileira de Sementes, v.24, n.2, p.43-48, 2002. www.scielo.br/pdf/rbs/v24n2/v24n2a08.pdf

VIEIRA, R.D.; KRZYZANOWSKI, F.C. Teste de condutividade elétrica. In: KRZYZANOWSKI, F.C.; VIEIRA, R.D.; FRANÇA-NETO, J.B. (Ed.). Vigor de sementes: conceitos e testes. Londrina: ABRATES, 1999, p.1-26. 